\title{
Differences in susceptibility of palaemonid shrimp species to yellow head virus (YHV) infection
}

\author{
Siwaporn Longyant ${ }^{1}$, Paisarn Sithigorngul ${ }^{1, *}$, Parin Chaivisuthangkura ${ }^{1}$, \\ Sombat Rukpratanporn ${ }^{2}$, Weerawan Sithigorngul ${ }^{1}$, Piamsak Menasveta ${ }^{3}$
}

\author{
${ }^{1}$ Department of Biology, Srinakharinwirot University, Bangkok 10110, Thailand \\ ${ }^{2}$ Marine Biotechnology Research Unit, National Center for Genetic Engineering and Biotechnology, \\ Ministry of Science, Technology and Environment, and ${ }^{3}$ Department of Marine Science, Chulalongkorn University, Bangkok \\ 10330, Thailand
}

\begin{abstract}
Five species of palaemonid shrimp, Macrobrachium rosenbergii, M. lanchesteri, M. sintangense, Palaemon styliferus and P. serrifer, were collected from Penaeus monodon farming areas in Thailand. Some of each species were artificially infected with yellow head virus (YHV) by injection and then monitored by RT-PCR and by immunohistochemistry using monoclonal antibodies specific to $116 \mathrm{kDa}, 64 \mathrm{kDa}$, and $20 \mathrm{kDa}$ proteins of YHV. Natural YHV infections were not detected in any of the shrimp examined. In YHV injection experiments, a high proportion of $P$. serrifer, $P$. styliferus and $M$. sintangense exhibited mild to moderate YHV infections at $3 \mathrm{~d}$ post-injection. The severity of infection was reduced in shrimp that survived to 10 and $30 \mathrm{~d}$ post-injection. Using immunohistochemistry and RT-PCR, a small proportion of M. lanchesteri showed very mild YHV infections at Day 3 but no infections at Days 10 and 30. No YHV infections resulted in $M$. rosenbergii. The evidence suggested that $M$. sintangense, $P$. styliferus and $P$. serrifer are susceptible to YHV and carry it for some time. In contrast, $M$. rosenbergii and $M$. lanchesteri appear to resist YHV infection and eliminate YHV efficiently. Because they display a range of responses to YHV, palaemonid shrimp may serve as a good model for studying YHV defense mechanisms in shrimp.
\end{abstract}

KEY WORDS: Carrier $\cdot$ Immunohistochemistry $\cdot$ Macrobrachium lanchesteri $\cdot$ M. rosenbergii $\cdot$ M. sintangense $\cdot$ Palaemon serrifer $\cdot$ P. styliferus $\cdot$ Yellow head virus $\cdot$ YHV

\section{INTRODUCTION}

Shrimp aquaculture is a major industry in Thailand and many other countries. It provides high employment opportunities and a high-quality food product that generates billions of US dollars in annual revenue. However, the major viral diseases yellow head virus (YHV) and white spot syndrome virus (WSSV) can cause heavy production losses through mass mortality. Since no therapeutic treatments are available, disease control emphasizes preventative measures such as removal of potential carriers from the rearing system (Flegel et al. 1997). A wide host range has been demonstrated for WSSV and includes penaeid shrimp (Penaeus monodon, P. japonicus, P. penicillatus, P. se- misulcatus, $P$. indicus, $P$. setiferus, $P$. vannamei, $P$. stylirostris, Metapenaeus ensis), crabs (Scylla serrata, Charybdis feriatus, Portunus pelagicus, $P$. sanguinolentus, Sesarma sp., Uca pugilator, Helice tridens) palaemonid shrimp (Macrobrachium rosenbergii, M. lamerrae, M. idella, small pest palaemonid shrimp), krill (Acetes sp.), crayfish (Pacifastacus leniusculus, Procambarus clakii), copepods and insect larvae of Ephydriedae (Lo et al. 1996, Supamattaya et al. 1998, Kanchanaphum et al. 1998, Peng et al. 1998, Chen et al. 2000, Hameed et al. 2000, Maeda et al. 2000, Jiravanichpaisal et al. 2001, Panjota \& Lightner 2003), as determined by polymerase chain reaction (PCR) and in situ hybridization. By contrast, studies on YHV carrier species are very limited. For example, preliminary 
experiments performed by the National Institute for Coastal Aquaculture (NICA) of Thailand showed that $P$. merguiensis and $M$. ensis could be infected by injection of YHV and that injection of extracts of krill Acetes sp. captured from ponds containing YHV-infected P. monodon could cause disease in healthy P. monodon (Flegel et al. 1995). Another study revealed that Palaemon styliferus, a small and common resident of shrimp ponds, survived well after being fed with YHVinfected P. monodon (Flegel et al. 1995).

We report here on the survey of various palaemonid shrimp species commonly found in and around Penaeu$s$ monodon-rearing ponds for the presence of natural YHV infections. We also assessed the species as potential YHV carriers by experimental YHV infection. YHV detection was achieved by RT-PCR and confirmed by immunohistochemistry using monoclonal antibodies V3-2B, Y18 and Y19 specific to gp116, gp64 and p20 of YHV, respectively (Sithigorngul et al. 2000, 2002, Jitrapakdee et al. 2003). These proteins were previously described as 135, 67 and $22 \mathrm{kDa}$ proteins, respectively, by Nadala et al. (1997). The V3-2B antibody is specific to pathogenic YHV endemic in Thailand, while the Y18 and Y19 antibodies cross-react with several YHV variants including gill-associated virus (GAV) from Australia (Sithigorngul et al. 2002, Soowannayan et al. 2003).

\section{MATERIALS AND METHODS}

Animal collections. Macrobrachium lanchesteri (adult, 0.5 to $1 \mathrm{~g}$ ), $M$. rosenbergii (juvenile, 2 to $10 \mathrm{~g}$ ), M. sintangense (juvenile and adult, 1 to $3 \mathrm{~g}$ ), Palaemon styliferus (juvenile and adult, 1 to $3 \mathrm{~g}$ ) and Penaeus monodon (juvenile, 15 to $25 \mathrm{~g}$ ) were collected from a $P$. monodon farm and nearby canals in Prasamutjedee district, Samutprakarn province, Thailand. Some of the $M$. rosenbergii (adult female 15 to $20 \mathrm{~g}$ ) were obtained from a freshwater farm in Ayuthaya province. Palaemon serrifer (adult, 0.3 to $0.8 \mathrm{~g}$ ) were collected from a mangrove forest near a $P$. monodon farm in Chonburi province. All shrimp were maintained in 5, 10 or 25 ppt diluted seawater according to their natural habitats (Table 1) and fed with commercial P. monodon feed pellets.

YHV infection. For each shrimp species, 10 to 15 individuals were used to detect natural infections. The remainder were injected at approximately $1 \mu \mathrm{g}$ body weight ${ }^{-1}$ with filtrate $(0.45 \mu \mathrm{m})$ of a 1:500 dilution of hemolymph from Penaeus monodon experimentally infected with YHV. Thereafter, they were tested at 3, 10 and $30 \mathrm{~d}$. P. monodon from a farm were treated in the same fashion. Experiments were replicated in some species as indicated in Table 1.

Table 1. Infection of yellow head virus (YHV) in palaemonid shrimp determined by RT-PCR and immunohistochemistry (IHC). In the case of RT-PCR, all the samples were pooled as indicated by total number of shrimp in parentheses. In the case of IHC, individual shrimp were immunohistochemically stained; indicated in parentheses is the number of individuals that gave positive or negative results over the number of shrimp tested. -: undetectable; \pm : slightly detectable; + : detectable; ++ : frequently detectable; +++: very frequently detectable. ${ }^{*}$ : replicate experiments; the number of replicates depended on the availability of shrimps in each species. The number of shrimp that died in the initial experiment during the 3 to $30 \mathrm{~d}$ interval postinjection (PI) of YHV is shown in the last column. The shrimps that died during the 0 to $3 \mathrm{~d}$ interval PI were not counted since most of them died from trauma during collecting and handling processes. The total number of shrimp in each species in the initial experiment was equal to the number of shrimp in the last column plus the number of shrimp on Day 3 and Day 0. ND: not done

\begin{tabular}{|c|c|c|c|c|c|c|c|}
\hline Species & $\begin{array}{c}\text { Salinity } \\
\text { (ppt) }\end{array}$ & $\begin{array}{c}\text { Detection } \\
\text { method }\end{array}$ & $\begin{array}{c}\text { Natural } \\
\text { infection } \\
0\end{array}$ & $L^{\mathrm{D}}$ & $\begin{array}{l}\text { S after YHI } \\
\text { njection } \\
10\end{array}$ & 30 & $\begin{array}{l}\text { No. of dead } \\
\text { shrimp during } \\
3-30 \text { d PI/total }\end{array}$ \\
\hline Macrobrachium rosenbergii & 5 & $\begin{array}{c}\text { RT-PCR } \\
\text { IHC }\end{array}$ & $\begin{array}{l}-(15) \\
-(15) \\
-(10)^{*} \\
-(10)^{*}\end{array}$ & $\begin{array}{l}-(15) \\
-(15) \\
-(10)^{*} \\
-(10)^{*}\end{array}$ & $\begin{array}{c}-(15) \\
-(15) \\
\text { ND } \\
\text { ND }\end{array}$ & $\begin{array}{c}-(15) \\
-(15) \\
\text { ND } \\
\text { ND }\end{array}$ & $1 / 35$ \\
\hline M. lanchesteri & 5 & $\begin{array}{c}\text { RT-PCR } \\
\text { IHC }\end{array}$ & $\begin{array}{l}-(15) \\
-(15) \\
-(12)^{*}\end{array}$ & $\begin{array}{c} \pm(15) \\
\pm(1 / 15) \\
\pm(1 / 12)^{*}\end{array}$ & $\begin{array}{c}-(15) \\
-(15) \\
\text { ND }\end{array}$ & $\begin{array}{c}-(15) \\
-(15) \\
\text { ND }\end{array}$ & $0 / 50$ \\
\hline M. sintangense & 10 & $\begin{array}{c}\text { RT-PCR } \\
\text { IHC }\end{array}$ & $\begin{array}{l}-(15) \\
-(15) \\
-(12)^{*}\end{array}$ & $\begin{array}{c}+++(15) \\
++(15) \\
++(8 / 12)^{*}\end{array}$ & $\begin{array}{c}+++(15) \\
+(15) \\
\text { ND }\end{array}$ & $\begin{array}{c}+++(15) \\
+(6 / 15) \\
\text { ND }\end{array}$ & $74 / 108$ \\
\hline Palaemon styliferus & 10 & $\begin{array}{c}\text { RT-PCR } \\
\text { IHC }\end{array}$ & $\begin{array}{l}-(10) \\
-(10) \\
-(15)^{*}\end{array}$ & $\begin{array}{c}+++(10) \\
++(9 / 10) \\
++(12 / 15)^{*}\end{array}$ & $\begin{array}{c}+++(10) \\
+ \pm(8 / 10) \\
\text { ND }\end{array}$ & $\begin{array}{c}+(5) \\
+(3 / 5) \\
\text { ND }\end{array}$ & $38 / 53$ \\
\hline P. serrifer & 25 & $\begin{array}{c}\text { RT-PCR } \\
\text { IHC }\end{array}$ & $\begin{array}{l}-(12) \\
-(12)\end{array}$ & $\begin{array}{l}+++(12) \\
++(8 / 12)\end{array}$ & $\begin{array}{l}+++(12) \\
++(8 / 12)\end{array}$ & $\begin{array}{l}+++(12) \\
+(8 / 12)\end{array}$ & $2 / 40$ \\
\hline
\end{tabular}


Sample preparation. Shrimp were killed by placing in ice-cold water. The head portion was cut longitudinally and divided in half. One half was fixed in Davidson's fixative and processed for paraffin sectioning at $8 \mu \mathrm{m}$ thickness to detect YHV infection by immunohistochemistry. The other half was placed in extraction buffer $(50 \mu \mathrm{M}$ Tris-HCl pH 9, $100 \mathrm{mM}$ EDTA, $50 \mathrm{mM}$ $\mathrm{NaCl}, 2 \% \mathrm{SDS}$ ) at the proportion of approximately $1 \mathrm{~g}$ of tissue $5 \mathrm{ml}$ buffer ${ }^{-1}$ and stored at $-20^{\circ} \mathrm{C}$ until used for detection of YHV by RT-PCR.

Immunohistochemical detection of YHV. Head sections of the various shrimp species were deparaffinized, rehydrated and processed for indirect immunoperoxidase antibody staining. Monoclonal antibodies specific to gp116 protein (V3-2B; Sithigorngul et al. 2000), gp64 and $20 \mathrm{kDa}$ proteins (Y18 and Y19; Sithigorngul et al. 2002) were used as primary antibodies on consecutive sections for each specimen. Goat antimouse immunoglobulin IgG H\&L horseradish peroxidase conjugate (BioRad) was used as the secondary antibody. Peroxidase activity was revealed by incubation with $0.03 \%$ diaminobenzidine, $0.006 \%$ hydrogen peroxide in phosphate-buffered saline (PBS) $(0.15 \mathrm{M}$ PBS, pH 7.2), then counter-stained with haematoxylin and eosin $Y$, and processed for permanent slides. The control experiment was performed by either omitting the primary antibody or by monoclonal antibody replacement with a monoclonal antibody to WSSV.
Detection of YHV infection by RT-PCR. Shrimp tissues were pooled in extraction buffer and ground with a mortar and pestle. Then, $200 \mu \mathrm{l}$ of the homogenate was used for nucleic acid extraction using a High Pure viral nucleic acid extraction kit (Roche Molecular Biochemicals). Extracted nucleic acid was then amplified by RT-PCR using a SuperScript 1-step RT-PCR system (GIBCO BRL) with primers YHV 10F (CCG CTA ATT TCA AAA ACT ACG) and 144R (AAG GTG TTA TGT CGA GGA AG) (Wongteerasupaya et al. 1997) that result in a PCR product of $135 \mathrm{bp}$. To confirm that the causative agent of the infection was YHV and not gill associated virus (GAV), shrimp samples that gave positive results at $3 \mathrm{~d}$ post-YHV injection were subjected to a test with an IQ2000 YHV/GAV RT-PCR test kit (Farming IntelliGene Technology Corporation) that gave a $207 \mathrm{bp}$ amplicon for YHV and a $406 \mathrm{bp}$ amplicon for GAV.

\section{RESULTS}

No natural infections of YHV were detected in any of the collected individuals (Fig. 1) using either RT-PCR or immunohistochemical methods. After YHV injection, all Penaeus monodon died within $2 \mathrm{~d}$ and showed heavy YHV infection in various organs using all 3 antibodies, as previously reported (Soowannayan et al.
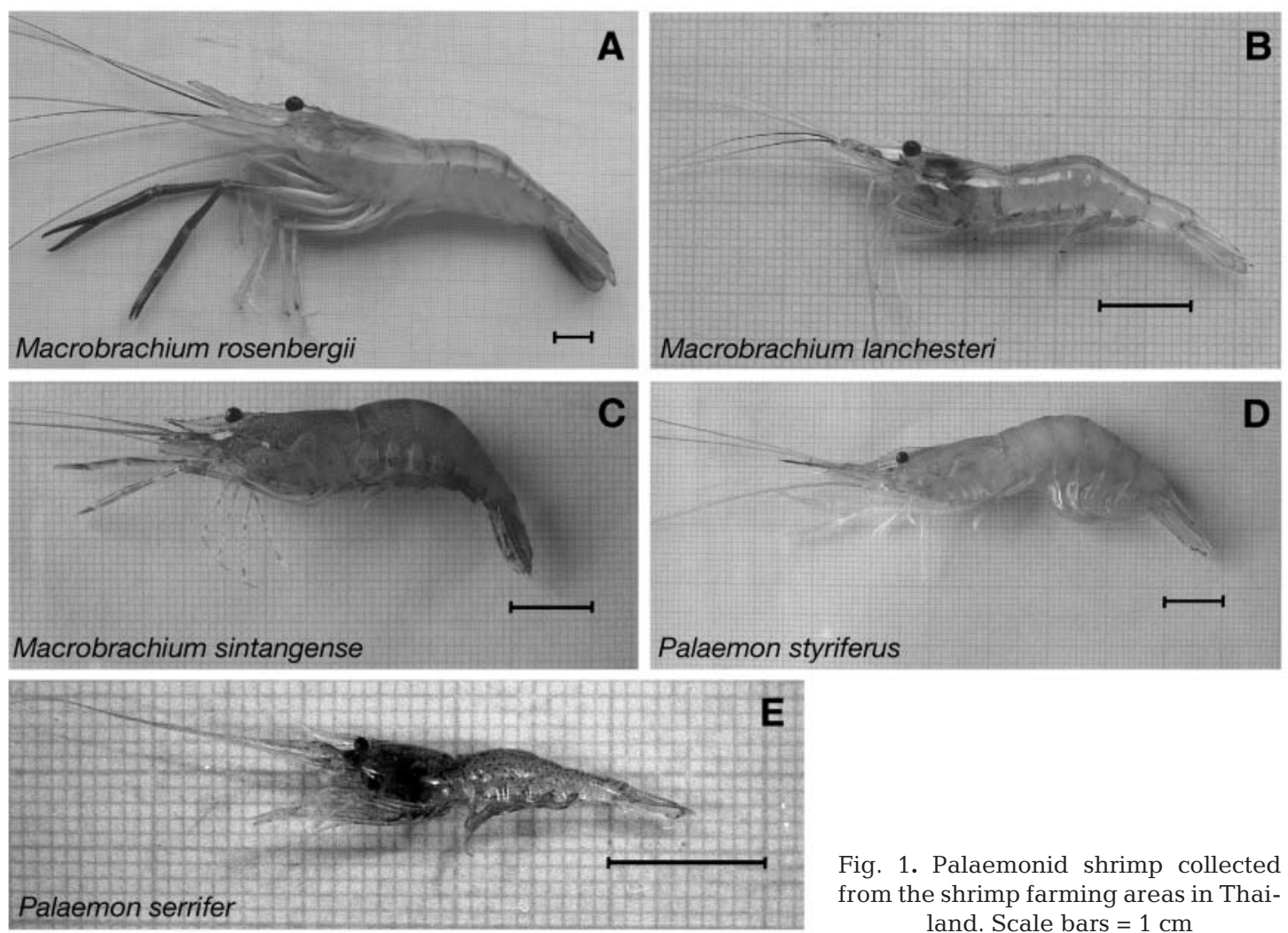

Fig. 1. Palaemonid shrimp collected from the shrimp farming areas in Thailand. Scale bars $=1 \mathrm{~cm}$ 
2002). PCR analysis with YHV-specific primers confirmed that infection was due to YHV and not GAV (data not shown).

No YHV infection was detected in YHV-injected Macrobrachium rosenbergii using either RT-PCR or
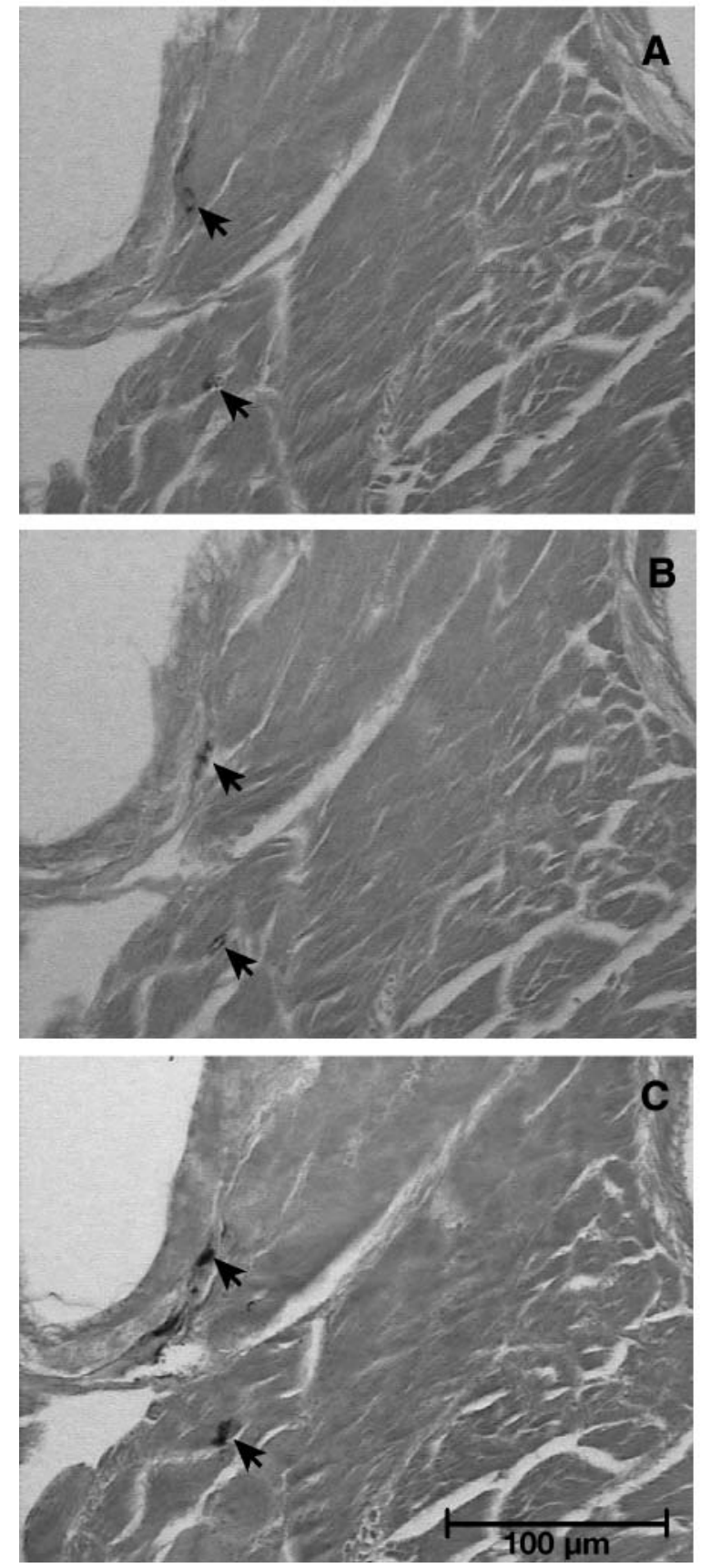

Fig. 2. Macrobrachium lanchesteri infected with yellow head virus (YHV). Immunohistochemical detection of YHV using monoclonal antibodies (MAbs) against gp64 (A, Y18), gp116 (B, V3-2B) and $20 \mathrm{kDa}$ protein (C, Y19) with appendage muscle of $M$. lanchesteri $3 \mathrm{~d}$ after injection with YHV. The specimen was counter-stained with eosin Y. Immunoreactivity was very faint and rarely observed (arrows) immunohistochemistry from Days 3 to 30 post-injection (Table 1). Shrimp subjected to double injection in other experiments showed similar results (data not shown).

Very mild YHV infections were detected by immunohistochemistry and RT-PCR in the hepatopancreas and muscle of mouth appendages in a few (1/15 and 1/12) Macrobrachium lanchesteri individuals at $3 \mathrm{~d}$ post-YHV injection (Table 1, Fig. 2 and see Fig. 6). At high magnification, the immunohistochemical reaction could be seen to reside in the cell cytoplasm. It is unlikely that this reaction resulted from residual cells in the YHV inoculum since it had been passed through a membrane filter. No YHV could be detected by the same methods at 10 and $30 \mathrm{~d}$ post-injection.

Moderate YHV infections were detected by immunohistochemistry in Macrobrachium sintangese, $\mathrm{Pa}$ laemon styliferus, and $P$. serrifer at $3 \mathrm{~d}$ post-injection. Results are illustrated here for only 1 to 2 tissues in each species (Figs. 3-5). A curious feature of the reactions was that adjacent sections of some tissues, such as interstitial cells of the hepatopancreas, nerve ganglia, testes and ovaries, gave strong immunoreactions with Y18 and Y19 antibodies in many cells but weak immunoreactions with V3-2B antibody in only a few cells (Figs. $3 \& 4$ ). By contrast, in the same specimens, some tissues such as muscle gave strong and similar immunoreactivities with all 3 antibodies (Fig. 5). In addition, all 3 antibodies gave similar, strong reactions in all infected tissues of Penaeus monodon. RT-PCR determinations revealed that the infections were not caused by a GAV-like virus that has been reported to give differential reactions with the 3 antibodies used here (Soowannayan et al. 2003). During the 3 to $30 \mathrm{~d}$ interval post-injection, approximately $70 \%$ of $M$. sintangense and $P$. styliferus died during molting. The severity of YHV infection in the surviving shrimp was reduced at 10 and $30 \mathrm{~d}$ post-injection. In contrast, very few $P$. serrifer died during the $30 \mathrm{~d}$ post-injection period (Table 1).

Results from YHV detection by RT-PCR agreed with those from immunohistochemistry. All sets of injected Macrobrachium sintangense, Palaemon styliferus and $P$. serrifer gave distinct $135 \mathrm{bp}$ amplicons. In M. lanchesteri, a very light band was observed in shrimp at $3 \mathrm{~d}$ after YHV injection but no bands were observed at 10 and $30 \mathrm{~d}$ (Fig. 6). Using the IQ 2000 YHV/GAV kit, all infections gave predicted amplicons for YHV but not for GAV-like virus.

\section{DISCUSSION}

Successful laboratory infections of YHV in Macrobrachium sintangense, Palaemon styliferus and $P$. serrifer supported previous speculation from feeding 

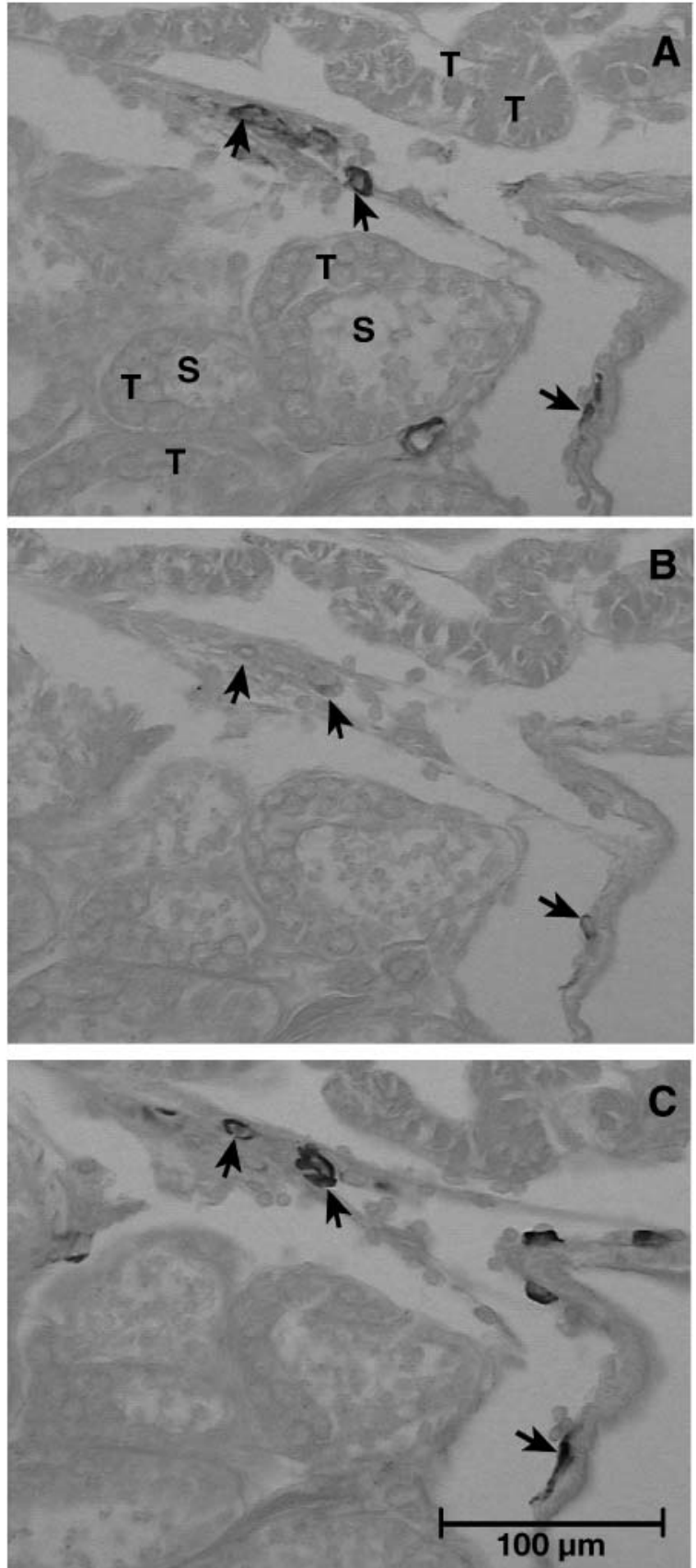

Fig. 3. Macrobrachium lanchesteri infected with yellow head virus (YHV). Immunohistochemical detection of YHV using MAbs as indicated in Fig. 2 with the testis of $M$. sintangense $3 \mathrm{~d}$ after injection with YHV. In connective tissue surrounding tubules, immunoreactivities with MAbs Y18 and Y19 are strong while immunoreactivity with $\mathrm{V} 3-2 \mathrm{~B}$ is light and appears in only a few cells (arrows). $\mathrm{T}=$ wall of testicular tubule, $\mathrm{S}=$ spermatozoa

experiments that $P$. styliferus might be a carrier of YHV (Flegel et al. 1995). The fact that $M$. sintangense and $P$. styliferus died during molting and mostly while still attached to their exuvia, indicated that YHV mor-
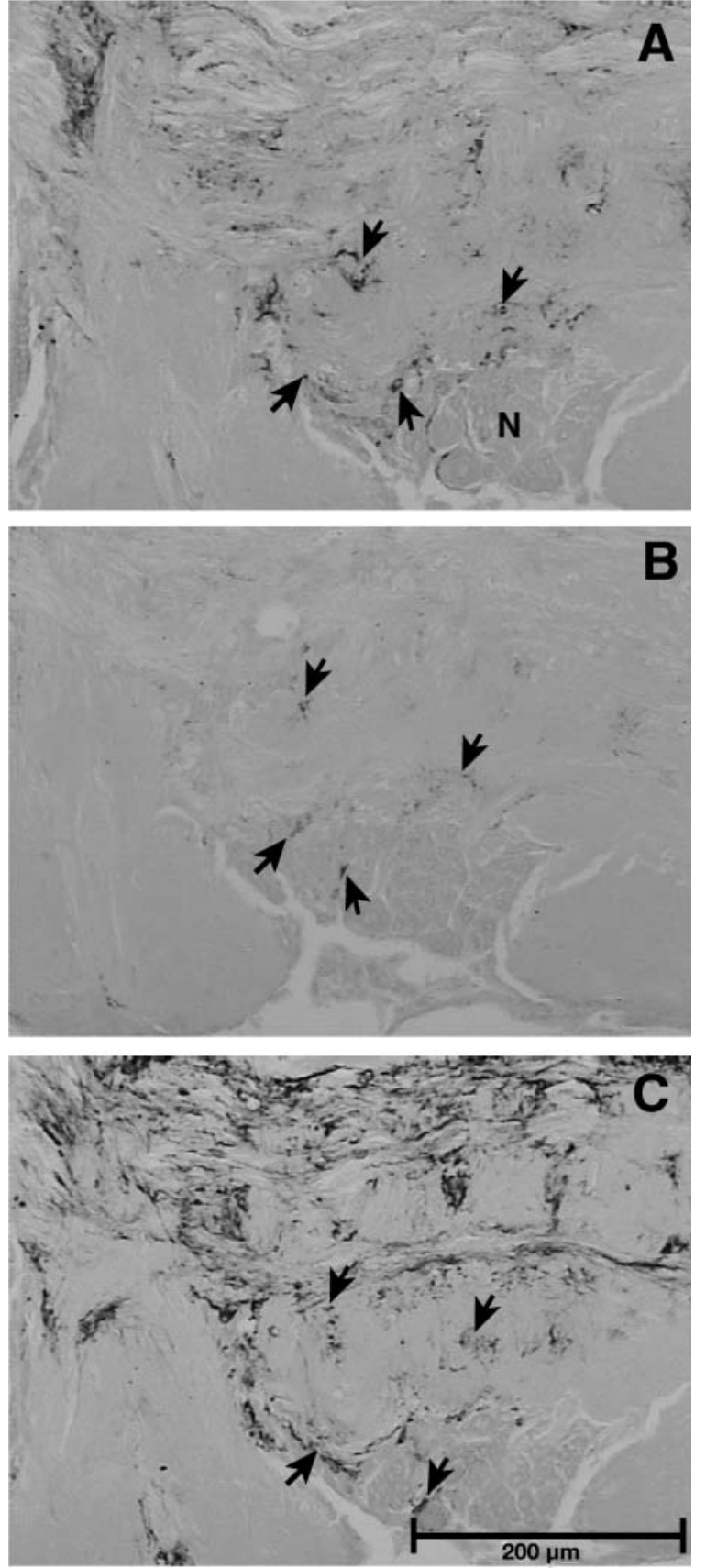

Fig. 4. Macrobrachium lanchesteri infected with yellow head virus (YHV). Immunohistochemical detection of YHV using MAbs as indicated in Fig. 2 with the thoracic ganglion of Palaemon serrifer $3 \mathrm{~d}$ after injection with YHV. The results were similar to those of Fig. 3. $\mathrm{N}=$ neuronal cell bodies in the thoracic ganglion

tality may be triggered by molting or that YHV infection may interfere with molting or stimulate premature molting. Since the severity of infection in surviving shrimp appeared to decrease with time, it appeared 

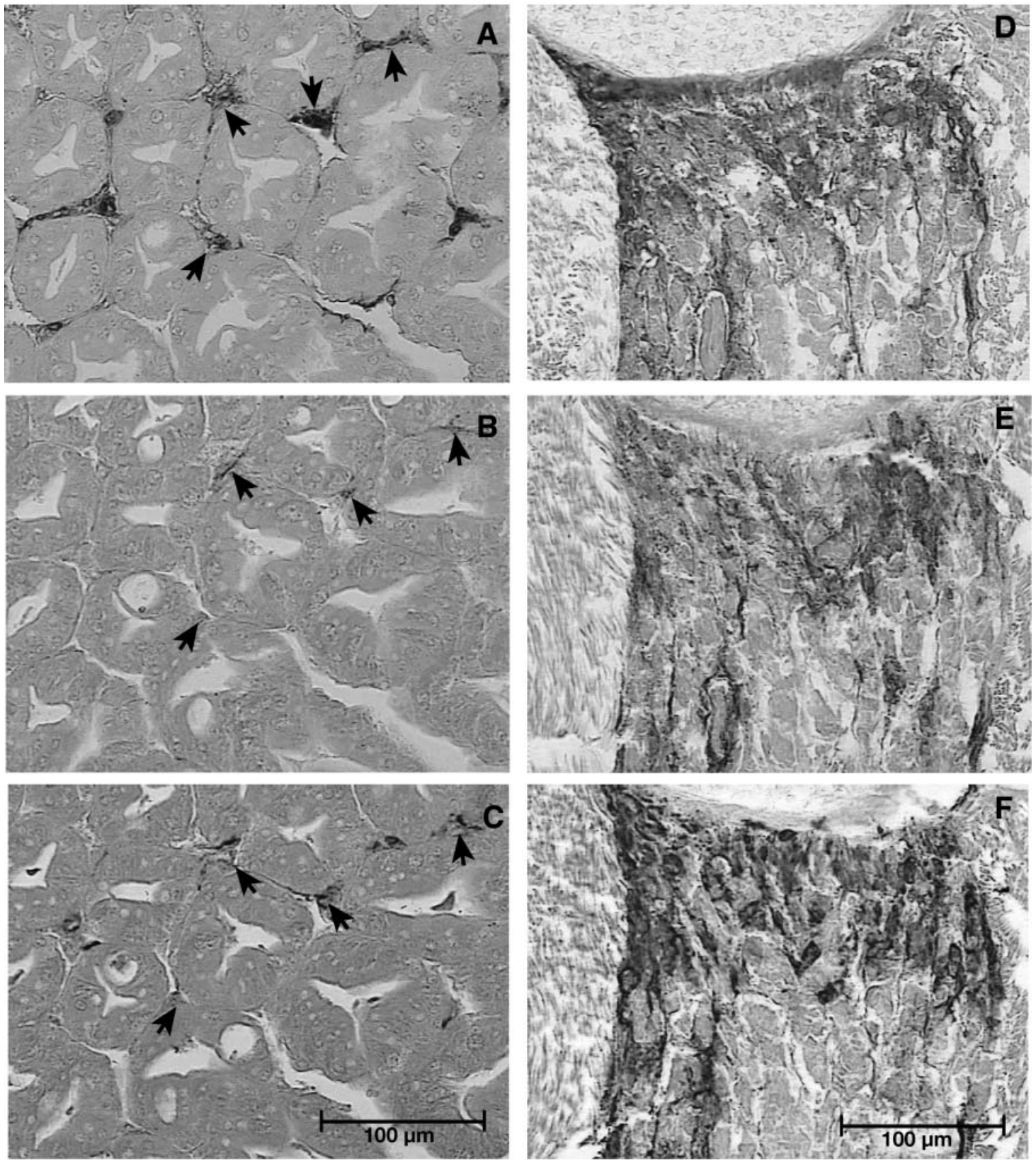

Fig. 5. Macrobrachium lanchesteri infected with yellow head virus (YHV). Immunohistochemical localization of YHV using MAbs as indicated in Fig. 2 with the hepatopancreas (A-C) and nearby muscle region (D-F) of Palaemon styliferus $3 \mathrm{~d}$ after YHV injection. The results with the hepatopancreas were similar to those in Figs. 3 \& 4, but in the nearby muscle region (D-F), immunoreactivities were strong with all 3 antibodies

that they might have mechanisms to control the spread of the virus.

The occurrence of only very light YHV infections in a limited number of Macrobrachium lanchesteri, and only at $3 \mathrm{~d}$ post-YHV injection but not at $10 \mathrm{~d}$ suggested that the species was capable of eliminating YHV. M. rosenbergii appeared to be refractory to
YHV infection even after double challenge. Thus, it appears unlikely that these species would be YHV carriers that could pose a threat to shrimp farmers. M. rosenbergii also appears to be resistant to WSSV infection (Hameed et al. 2000), at least at the adult stage. On the other hand, it has been reported that larval $M$. rosenbergii are susceptible to WSSV infec- 


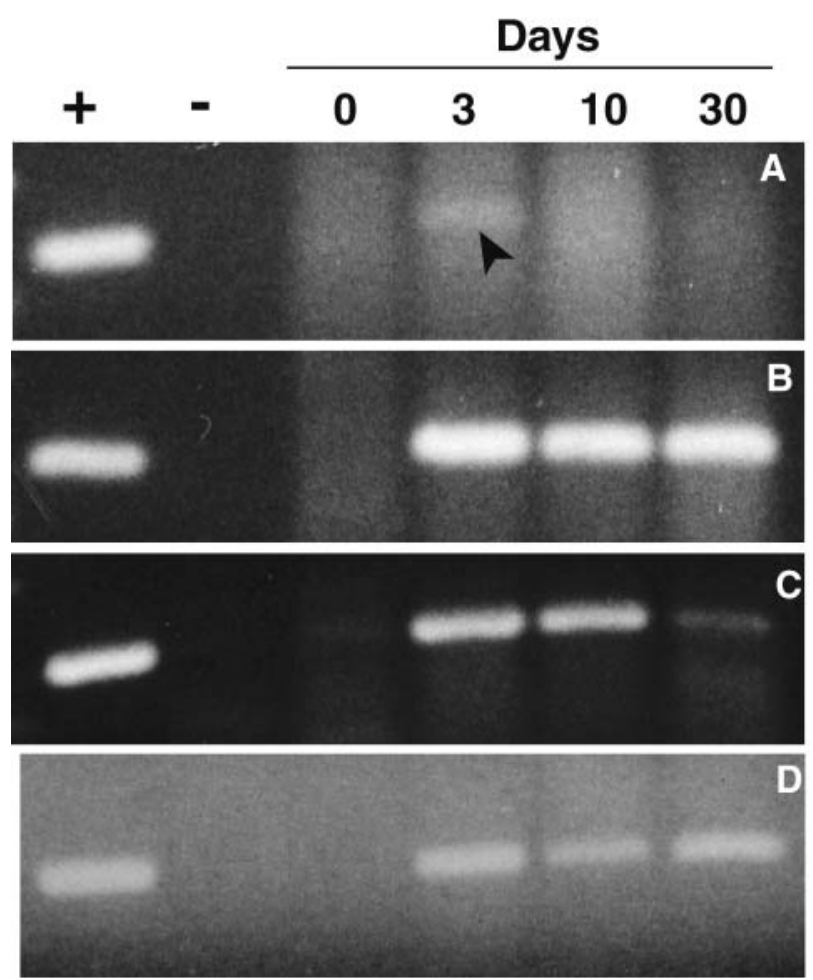

Fig. 6. RT-PCR products of tissues from control (non-injected) shrimp (0) and injected shrimp 3, 10, $30 \mathrm{~d}$ after challenge. (A) Macrobrachium lanchesteri, (B) M. sintangense, (C) Palaemon styliferus, (D) P. serrifer. $+=$ positive control,$-=$ negative control. In $M$. lanchesteri, the RT-PCR product occurred very faintly only at $3 \mathrm{~d}$ after YHV injection (arrowhead)

tion and may carry it for life if they survive (Lo et al. 1996, Peng et al. 1998). It would be necessary to check larval stages of $M$. lanchesteri and $M$. rosenbergii to see whether this might occur with YHV, although the failure to find any specimens naturally infected with YHV argues against the possibility of this happening in a natural setting.

The fact that Macrobrachium rosenbergii is resistant to WSSV and YHV infection might encourage some shrimp farmers to consider co-cultivating it with Penaeus monodon or other penaeid shrimp as a scavenger to eat dead and moribund YHV, and WSSVinfected shrimp and thus limit the spread of disease in rearing ponds. However, this practice should be strongly discouraged since crustaceans are known to carry cryptic viral pathogens (Flegel 2001). Such practices would promote and select for cross-species transfer of viral pathogens. This is particularly important for RNA viruses such as YHV since they are known to have high mutation rates.

The occurrence of persistent YHV infections in Macrobrachium sintangense, Penaeus styliferus and P. serrifer indicated that they are potential YHV carriers that could pose a threat to shrimp farmers. $P$. serrifer would be particularly dangerous due to its high tolerance and ability to survive for long periods of time. Moreover, $P$. serrifer may be able to vertically transmit YHV, since viral proteins were observed in interstitial cells surrounding the ovum and male reproductive tract. It has been shown in Penaeus monodon that the YHV-complex virus GAV can be vertically transmitted via the male or female reproductive tract (Cowley et al. 2002).

Since we observed no natural YHV infections in the palaemonid shrimp sampled, it is possible that they are unlikely to be infected naturally at low viral titres in water. Perhaps high oral doses from ingestion of dead or dying shrimp would be required, as was suggested by earlier work in Thailand.

A curious feature of our work was the highly diminished immunohistochemical reaction observed in some tissues with monoclonal antibodies (MAbs) V3-2B, specific to the YHV envelope glycoprotein gp116. This contrasted with strong reactions in the same tissues using MAbs Y18 and Y19, specific to gp64 and a $20 \mathrm{kDa}$ structural protein, respectively. The difference in reaction was most likely due to differential expression of the relevant target proteins, since the 3 MAbs reacted equally in Penaeus monodon and in adjacent tissues of some of the tested palaemonid shrimp. This in turn suggested that expression of gp116 protein was somehow differentially suppressed, and it raises the question as to whether lack of its expression might be related to limited spread of the virus in vivo. If so, it might explain why these shrimp species can tolerate YHV infection and survive longer than $P$. monodon.

Both gp116 and gp64 are encoded in ORF3 of YHV and undergo post-translational proteolytic cleavage and glycosylation (Jitrapakdee et al. 2003). Thus, it is unlikely that the cell would be able to suppress the expression of glycoprotein gp116 protein only. A more likely possibility might be deletion of the N-terminus of the gp116 protein that contains the epitope target of V3-2B antibody (C. Soowannayan pers. comm.). A similar pattern of antibody staining has also been observed in healthy Penaeus monodon infected with a non-virulent YHV complex variant commonly found in Thailand (Soowanayan et al. 2003) and this pattern matches that for the Australian YHV-complex variant, GAV that lacks the V3-2B target epitope (Jitrapakdee et al. 2003). Altogether, the data suggest that the N-terminal sequence of gp116 may play an important role in YHV virulence. Therefore, further investigations should be carried out on the relationship between YHV virulence and gp116 expression. Study of this phenomenon and other aspects of YHV resistance in palaemonid shrimp should further our knowledge about potential protection mechanisms against YHV infection.

Our results suggest that the host range for YHV is likely to be narrower than that for WSSV. However, the 
fact that 3 common palaemonid species are potential carriers suggests that shrimp farmers should take precautions to prevent their introduction into rearing ponds, as is done for WSSV carriers (Flegel et al. 1997). However, more extensive sampling of natural populations of these species and more studies on YHV transmission are required before the full extent of the disease transfer risk from these species can be assessed.

Acknowledegments. This work was supported by the Srinakharinwirot University Research Fund and the National Center for Genetic Engineering and Biotechnology, Thailand. We are deeply grateful to Dr. William G. Bendena, Department of Biology, Queen's University, Kingston, Canada, for his kind suggestion and for editing this manuscript.

\section{LITERATURE CITED}

Chen LL, Lo CF, Chiu YL, Chang CF, Kou GH (2000) Natural and experimental infection of white spot syndrome virus (WSSV) in benthic larvae of mud crab Scylla serrata. Dis Aquat Org 40:157-161

Cowley JA, Hall MR, Cadogan LC, Spann KM, Walker PJ (2002) Vertical transmission of gill-associated virus (GAV) in the black tiger prawn Penaeus monodon. Dis Aquat Org 50:95-104

Flegel TW (2001). The shrimp response to viral pathogens. In: Browdy CL, Jory DE (eds) The new wave. Proceedings of the Special Session on Sustainable Shrimp Aquaculture, World Aquaculture 2001, Orlando. World Aquaculture Society, Boca Raton, FL, p 190-214

Flegel TW, Sriurairatana S, Wongteerasupaya C, Boonsaeng V, Panyim S, Withyachumnarnkul, B (1995) Progress in characterization and control of yellow-head virus of Penaeus monodon. In: Browdy C, Hopkins S (eds) Proc Special Session on Shrimp Farming, Aquaculture '95, San Diago, February 1995. World Aquaculture Society, Baton Rouge, FL, p 76-83

Flegel TW, Boonyaratpalin S, Withyachumnarnkul B (1997) Progress in research on yellow-head virus and white-spot virus in Thailand. Disease in Asian Aquaculture III. Fish Health Section, Asian Fisheries Society, Manila, p 285-295

Hameed ASH, Charles MX, Anilkumar M (2000) Tolerance of Macrobrachium rosenbergii to white spot syndrome virus. Aquaculture 183:207-213

Jiravanichpaisal P, Bangyeekhun E, Soderhall K, Soderhall I (2001) Experimental infection of white spot syndrome virus in freshwater crayfish Pacificus leniusculus. Dis Aquat Org 47:151-17

Jitrapakdee S, Unajak S, Sittidilokratana N, Hodgson RA, Cowley JA, Walker PJ, Panyim S, Boonsaeng V (2003)

Editorial responsibility: Timothy Flegel, Bangkok, Thailand
Identification and analysis of gp116 and gp64 structural glycoproteins of yellow head nidovirus of Penaeus monodon shrimp. J Gen Virol 84:863-873

Kanchanaphum P. Wongteerasupaya C, Sitidilokratana N, Boonsaeng V, Panyim S, Tassanakajon A, Wityachumnarnkul B, Flegel TW (1998) Experimental transmission of white spot syndrome virus (WSSV) from crabs to shrimp Penaeus monodon. Dis Aquat Org 34:1-7

Lo CF, Ho CH, Peng SE, Chen CH and 7 others (1996) White spot syndrome baculovirus (WSBV) detected in culture and captured shrimp, crabs and other arthropods. Dis Aquat Org 27:215-225

Maeda M, Itami T, Mizuki E, Tanaka R and 5 others (2000) Red swamp crawfish (Procambarus clarkii): an alternative experimental host in the study of white spot syndrome virus. Acta Virol 44:371-374

Nadala ECB, Tapay LM, Cao S, Loh PC (1997) Detection of yellow head virus and Chinese baculovirus in penaeid shrimp by western blot technique. J Virol Methods 69:39-44

Pantoja CR and Lightner DV (2003) Similarity between the histopathology of white spot syndrome virus and yellow head syndrome virus and its relevance to diagnosis of YHV disease in the Americas. Aquaculture 218:47-54

Peng SE, Lo CF, Ho CH, Chang CF, Kou GH (1998) Detection of white spot baculovirus (WSBV) in giant freshwater prawn, Macrobrachium rosenbergii, using polymerase chain reaction. Aquaculture 164:253-262

Sithigorngul P, Chauychuwong P, Sithigorngul W, Longyant S, Chaivisuthangkura P, Menasveta P (2000) Development of monoclonal antibody specific to yellow head virus (YHV) from Penaeus monodon. Dis Aquat Org 42:27-34

Sithigorngul $\mathrm{P}$, Rukpratanporn $\mathrm{S}$, Longyant $\mathrm{S}$, Chaivisuthangkura P, Sithigorngul W, Menasveta P (2002) Monoclonal antibodies specific to yellow-head virus (YHV) of Penaeus monodon. Dis Aquat Org 49:71-76

Soowannayan C, Sithigorngul P, Flegel TW (2002) Use of specific monoclonal antibody to determine tissue tropism of yellow head virus (YHV) of Penaeus monodon by in situ immunocytochemistry. Fish Sci (Suppl I):805-809

Soowannayan C, Flegel TW, Sithigorngul P, Slater J and 7 others (2003) Detection and differentiation of yellow head complex viruses using monoclonal antibodies. Dis Aquat Org 57:193-200

Supamattaya K, Hoffmann RW, Boonyaratpalin S, Kanchanaphum P (1998) Experimental transmission of white spot syndrome virus (WSSV) from black tiger shrimp Penaeus monodon to the sand crab Portunus peagicus, mud crab Scylla serrata and krill Acetes sp. Dis Aquat Org 32:79-85

Wongteerasupaya C, Tongchuea W, Boonsaeng V, Panyim S, Tassanakajon A, Withyachumnarnkul B, Flegel TW (1997) Detection of yellow-head virus (YHV) of Penaeus monodon by RT-PCR amplification. Dis Aquat Org 31: 181-186

Submitted: November 24, 2003; Accepted: September 22, 2004; Proofs received from author(s): January 31, 2005 